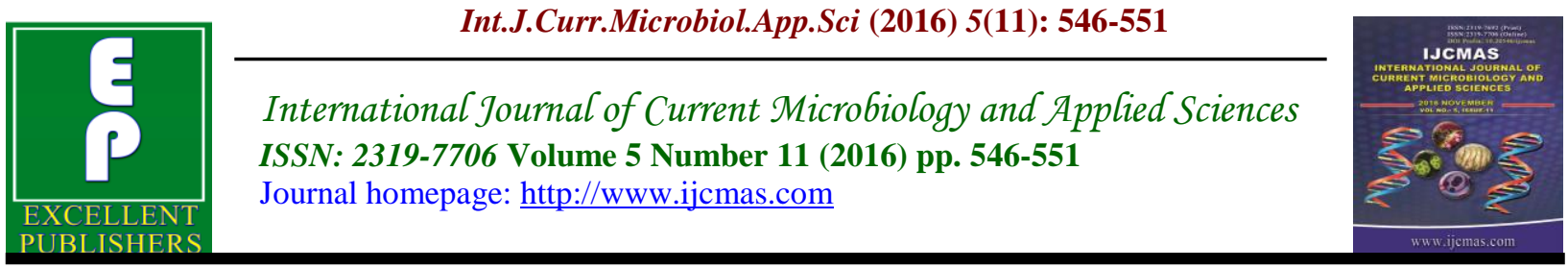

Original Research Article

http://dx.doi.org/10.20546/ijcmas.2016.511.065

\title{
Evaluation of Antibiotics Sensitivities against Some UTI Pathogens
}

\author{
Firyal N. Aziz* \\ Medical Microbiology / Assis.Prof / College of Medical and Health Technology \\ *Corresponding author
}

\section{A B S T R A C T}

\begin{tabular}{l} 
Ke y w o r d s \\
UTI, \\
Antibiotics \\
Sensitivity, \\
Enterobacteriacea. \\
\hline Article Info \\
\hline Accepted: \\
24 October 2016 \\
Available Online: \\
10 November 2016
\end{tabular}

\section{Introduction}

Since the advent of penicillin in (1940s) there were tremendous efforts by scientist to find new ones and prove the available antibiotics. However, the bacterium protect it self against the man weapon (i.e. antibiotics) by mutations or others means to survive. The struggle between the man and bacteria will continue for ever, but the lastword will be for the human.

Many workers devoted their times and efforts to find a suitable antibiotics which is less expensive and safe to use in man.

An investigation on children with UTI, denoting that $E$. coli was the infecting bacterium in majority of cases while, Proteus spp. was the next; most common and both were sensitive to Nalidixic acid, later it appeared that nalidixic acid is a drug of choice against E. coli and Proteus among children UTI cases (Kneebone, 1965). These facts was confirmed by other workers, when reported that Nalidixic acid is a valuable antibiotic agent for the treatment of E. coli (Newman, 1996). Two hundred and nine samples for UTI cases were undergone bacterial isolation in an investigation. It was demonstrated that $E$. coli is the most common organism isolated followed by Klebsiella spp. and Enterbacter spp. It was declared that $(46 \%)$ of these 
strains are sensitive to Nalidixic acid (Dytan et al., 1999). On the other hand, it was denoted that the resistance of Proteus strains for Penicillin, Tetracycline \& Streptomycin with highly sensitivity to Gentamicin (Dikyi, 1971).

Many studies confirmed Proteus sensitivity to Gentamicin and Sionicen. Regarding the Ampicillin, scientists reported that this antibiotic is highly effective against $E$. coli and P. mirabilis (Anderson et al., 1964). Similarly, it was found that 241 , bacteria which were isolated from patients with UTI, all were sensitive to ampicillin (Brumfitt et al., 1962). On the contrary other studies reported that (45) strains of Proteus mirabilis which were isolated from various clinical conditions were resistant to Ampicillin. Similarly with E. coli, studies revealed that $>50 \%$ of these strains which were urinary isolates, were resistant to Ampicillin (Rossi et al., 1999). While other study denoted that $65 \%$ of E. coli strains isolated from hospitalized children with UTI, were resistant to Ampicillin (Valdivieso et al., 1999).

More than $50 \%$ of (360) isolates of E. coli were sensitive to Gentamicin and Nitrofurantoin. On the other hand, among the cases of community acquired acute cystitis; Nitrofurantoin was observed the most effective drug not only for $E$. coli (90\%), but also for all the isolates (Achla et al., 2004).

Other antibiotic such as Nalidixic acid was reported to be the best against E. coli, Klebsiella spp. and Proteus spp. When different group of antimicrobial agents used against six different spp. of bacteria isolated from 200 cases of UTI and also reported that these strains were most found resistant to Ampicillin.
In spit of all new antibiotics still certain bacteria are resistant to antibiotics which cause trouble to patients and difficulties in their recovery. Therefore this research is planned to compare the locally synthesized drugs-sensitivity of UTI pathogens in comparison with imported ones, particularly those of English source.

\section{Materials and Methods}

\section{Bacterial strains}

Three bacterial species were tested: $E$. coli, Klebsiella spp. and Proteus spp. One hundred strains of each have been isolated from patients with UTI during the period of (2014-2015) which admitted to Al-Yarmok hospital, Baghdad, department of Bacteriology.

\section{Antibiotic-sensitivity assay}

All the isolates of $E$.coli, Klebsiella spp. and Proteus spp. strains were tested for sensitivity to various antibiotics. The sensitivity of bacteria to an antibiotics is demonstrated by a significant zone of inhibition around the disc, the technique was performed according to the single disc technique (Bauer et al., 1966). The antibiotics were used in the following concentration: Ampicillin (Am $25 \mu \mathrm{g} / \mathrm{ml}$ ), Cephotoxim(CTX $10 \mu \mathrm{g} / \mathrm{ml}$ ) Gentamicin (GM10 $\mu \mathrm{g} / \mathrm{ml}$ ), Nalidixic acid (NA $30 \mu \mathrm{g} /$ $\mathrm{ml}$ ) and Nitrofurantoin (NI $30 \mu \mathrm{g} / \mathrm{ml}$ )

\section{Results and Discussion}

In hospitals different types of antibiotics are used, the commonest one are Iraqi and English, the action of both types of antibiotics have been studied on 300 strains of E. coli, Klebsiella spp., Proteus spp. as shown in (Table 1) in terms of sensitivity test. This table shows the selected England- 
manufactured antibiotics. which are used to applied routinely in sensitivity test in order to treat UTIs. This table reveals that (NI) is the best antibiotics against $E$. coli strains and Kelbsiella. spp. isolated from UTIs $(80 \%$, $70 \%$ respectively), while (GM) is the drug of choice against Proteus spp. (80\%).

The action of Iraqi antibiotics on the same strains of bacteria was listed in (Table 2). The above table reveals that the efficiency of all these antibiotics was comparable to that for England-manufactured ones. However, the frequency of sensitive strains are low in comparison with that for English ones, though (NI) shows the highest frequencies of sensitivity as well as the English antibiotics

This study demonstrated that our products of antibiotics almost efficient as well as the English ones. This fact was demonstrated in figure 1. below.

Urinary tract infections (UTIs) have complex dynamics, with uropathogenic Escherichia coli (UPEC), the major causative agent, capable of colonization from the urethra to the kidneys in both extracellular and intracellular niches while also producing chronic persistent infections and frequent recurrent disease. UTIs remain a common problem in inpatient care. They are highly challenging to provide effective initial therapy without sensitivity data. The present study showed that the action of (NA) against $E$. coli and proteus spp. agree with other investigators who reported that $E$. coli and Proteus spp.which were isolated from children with UTI, were sensitive to nalidixic acid.

The results of the current study are comparable with those of other study that Gentamicin was active against Proteus spp. which were isolated from various clinical conditions.

The Iraqi antibiotics showed various activities against different strains as shown in Table 2. These findings are in agreement with other (Lode, 1975) about the sensitivity of Proteus to Gentamicin.

Table.1 Sensitivity tests' results among UTIs cases using English Antibiotics

\begin{tabular}{|c|c|c|c|c|c|c|}
\hline \multirow[t]{2}{*}{ Organism } & \multirow{2}{*}{$\begin{array}{l}\text { No. of } \\
\text { strains } \\
\text { tested }\end{array}$} & \multicolumn{5}{|c|}{ Frequency of Sensitive strains (\% of sensitive stains) } \\
\hline & & $\begin{array}{l}\operatorname{Am~(25} \\
\mu \mathrm{g} / \mathrm{ml})\end{array}$ & $\begin{array}{l}\text { CTX (10 } \\
\mu \mathrm{g} / \mathrm{ml})\end{array}$ & $\begin{array}{l}\text { GM ( } 10 \\
\mu \mathrm{g} / \mathrm{ml})\end{array}$ & $\begin{array}{l}\text { NA ( } 30 \\
\mu \mathrm{g} / \mathrm{ml})\end{array}$ & $\begin{array}{l}\text { NI ( } 30 \\
\mu g / \mathrm{ml})\end{array}$ \\
\hline E. coli & 100 & 40 & 70 & 75 & 63 & 80 \\
\hline Kebsiella spp & 100 & 48 & 55 & 57 & 60 & 70 \\
\hline Proteus spp & 100 & 65 & 78 & 80 & 55 & 75 \\
\hline
\end{tabular}

Table.2 Sensitivity tests' results among UTIs cases using Iraqi Antibiotics

\begin{tabular}{|c|c|c|c|c|c|c|}
\hline \multirow[t]{2}{*}{ Organism } & \multirow{2}{*}{$\begin{array}{l}\text { No. of } \\
\text { strains } \\
\text { tested }\end{array}$} & \multicolumn{5}{|c|}{ Frequency of Sensitive strains (\% of sensitive stains) } \\
\hline & & $\begin{array}{l}\operatorname{Am}(25 \\
\mu \mathrm{g} / \mathrm{ml})\end{array}$ & $\begin{array}{l}\text { CTX (10 } \\
\mu \mathrm{g} / \mathrm{ml})\end{array}$ & $\begin{array}{l}\text { GM ( } 10 \\
\mu \mathrm{g} / \mathrm{ml})\end{array}$ & $\begin{array}{l}\text { NA ( } 30 \\
\mu \mathrm{g} / \mathrm{ml})\end{array}$ & $\begin{array}{l}\text { NI ( } 30 \\
\mu \mathrm{g} / \mathrm{ml})\end{array}$ \\
\hline E. coli & 100 & 32 & 65 & 68 & 70 & 75 \\
\hline Kebsiella spp & $\mathbf{1 0 0}$ & 39 & 40 & 45 & 55 & 64 \\
\hline Proteus spp & 100 & 55 & 80 & 76 & 42 & 71 \\
\hline
\end{tabular}


Fig.1 Comparison of Inhibitory Sensitivity test frequencies of Iraqi Antibiotics with English one

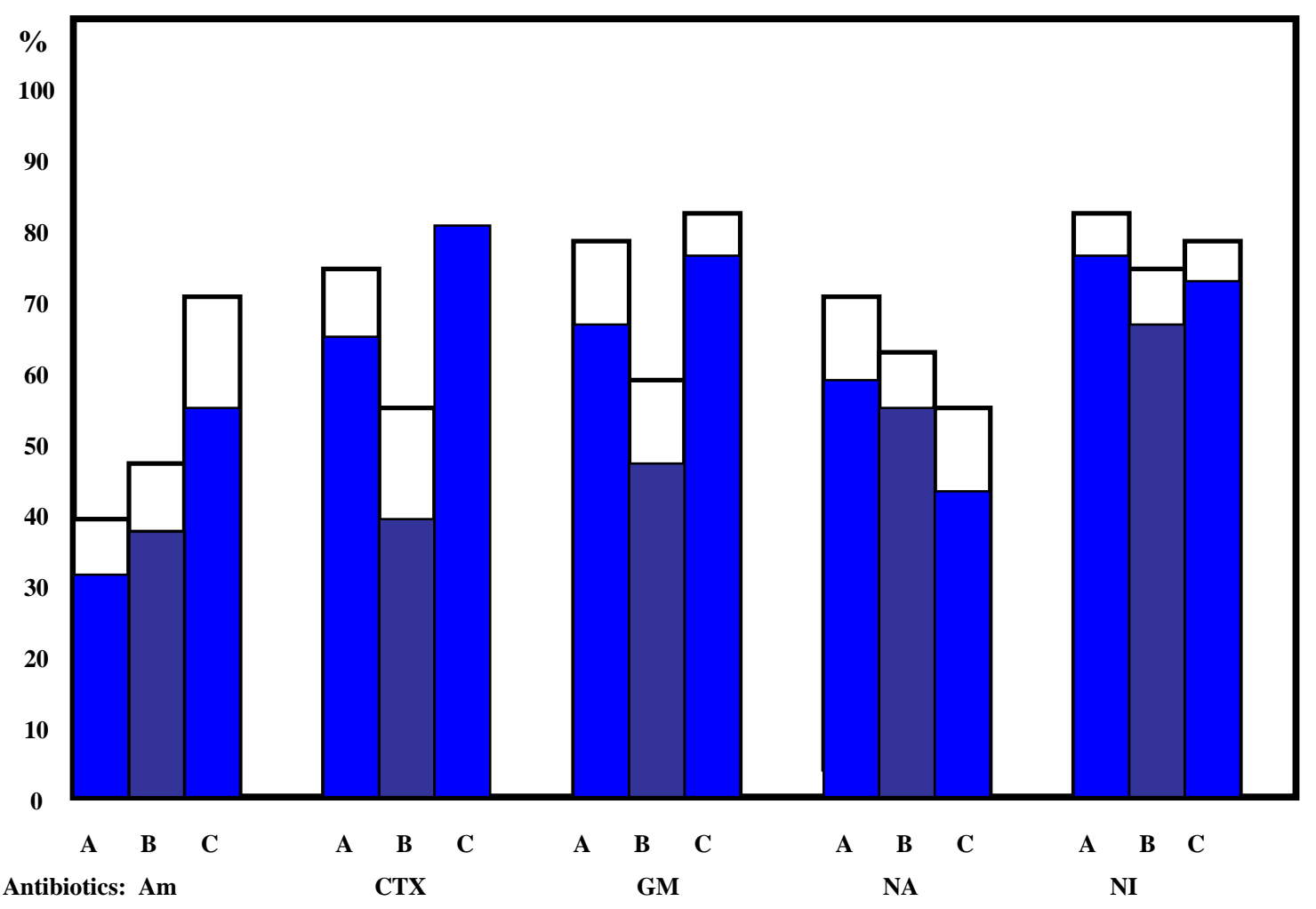

\section{A :E. coli \\ B: Klebsiella \\ C: Proteus}

On the contrary, the results of other investigators who, denoted that $(90 \%)$ of $E$. coli were inhibited by Ampicillin, meanwhile the current study indicated to (32\%) only which inhibited by Iraqi Ampicillin (Stratford, 1984). This variation is related to continuous mutations among bacterial strains which results in huge No. of resistant strains.

Furthermore the over-dosage or low-dose consuming of antibiotics beside prolong treatment with ampicillin during the last 20 years enhance the development of different bacterial virulence methods for resistance of antibiotic particularly Ampicillin and especially in Iraq. The highest resistant of $E$. coli and Klebsiella spp. against Ampicillin in other study were in agreement with the present study (Sharma et al., 2004).
Iraqi Antibiotics

English Antibiotics

Scientists declared that more than $(50 \%)$ of urinary tract isolated $E$. coli are resistant to Ampicillin. Other inestigators conducted a twelve month study in 11 children hospitals urinary isolates, they observed that (65\%) strains of $E$. coli were resistant to Ampicillin, (4.2\%) to Gentamicin and $(4.3 \%)$ to Nitro-furatoin which agree with this study's result.

Another study included 209 patients with UTI, which indicated to $E$. coli and Klebsiella pneumoniae as the most common isolates and (46\%) of these strains are sensitive to Nalidixic acid (3). Furthermore, it was observed that $(>90 \%)$ of Proteus spp isolates are sensitive to Nalidixic acid as well as the results of the current study (Huang et al., 1968). 
Regarding the effect of Gentamicin against Proteus spp. the result of the present study was compatible with other studies which showed that this bacterium; which isolated from UTI patients, is highly sensitive to Gentamicin (Shiba et al., 1971).

It was reported that more than $(50 \%)$ of UTI isolates were sensitive to Gentamicin and Nitrofuratoin as in the current study (11). Nitrofurantoin was observed to be the most effective drug not only for $E$. coli $(90 \%)$ but also for all the isolates (James et al., 2011) as in the current study.

From the general view, the English antibiotics against various bacteria were comparable to the Iraqi one in its action and this is because the Iraqi manufacturers during the last years; became more expert and skilled in antibiotics synthesis with high controls' parameters. Moreover they depended on the local strains for evaluation of their antibiotics products.

\section{References}

Achla, P., Sudha, V., Soni, G.R., Khare, S. \& Bhatia, R. 2004. Sensitivity index of antimicrobial agents: A new treatment criteria proposed for rational use of antimicrobials. Ind. J. Med. Micriobiol., 22(2): 107-11.

Anderson, K.N., Kennedy, R.P., Plorde, J.J., Shulman, J.A. \& Petersdorf. 1964. Effectiveness of ampicillin against gram-negative bacteria. J. Am. Med. Ass., 187: 555-61.

Azzarone, G., Liewehr, S., O'Connor, K. 2007. Cystitis. Pediatr Rev.. 28(12):474-6.

Bauer, A.W., Kirby, W.M.M., Sherris, J.C. \& Turk, M. 1966. Antibiotic susceptibility testing by a standardized single disc method. Am. J. Clin. Pathol. 45: 493-96.

Brumfitt, W., Percival, A. \& Carter, M.J. 1962. Treatment of urinary tract infections with ampicillin Lancet, 41016.

Colgan, R., Nicolle, L.E., McGlone, A., Hooton, T.M. Asymptomatic bacteriuria in adults. Am Fam Physician, 74(6): 985-90.

Conway, P.H., Cnaan, A., Zaoutis, T., Henry, B.V., Grundmeier, R.W., Keren, R. Recurrent urinary tract infections in children: risk factors and association with prophylactic antimicrobials. JAMA, 298(2):179-86.

Debasis, B., Pratima, G., Ramjee, P., Vikram, S., Muktanjali, A. \& Ashish, K. 2006. Choice of antibiotic for empirical therapy of acute cystitis in a setting of high antimicrobial resistance. Ind. $J$. Med. Sc. 60 (2): 53-58.

Dikyi, B.N. Sensitivity of various Proteus species to antibiotics. Antibiotiki, 16: 622-24.

Drew, J., Schwartz, Swaine, L., Chen, Scott J. Hultgren, and Patrick, C., Seed. 2011. Population Dynamics and Niche Distribution of Uropathogenic Escherichia coli during Acute and Chronic Urinary Tract Infection Infect. Immun., 79(10): 4250-4259.

Dytan, A.T. \& Chua, J.A. 1999. Surveillance of pathogens and resistance patterns in urinary tract infections. Phil. J. Microbiol. Infect. Dis., 28(1): 11-14.

Hone \& Foley. 1980. In vitro activities of mecillinum and mecillinum / ampicillin combination on Proteus species. $J$. antimicrobial chemo-therapy, 6: 410-16.

Huang, C.T. \& Chou, G. 1968. Drug sensitivity of Proteus species. J. Clin. Pathol., 21: 103-6.

James, A., Karlowsky, Philippe, R.S. LagacéWiens ,Patricia J. Simner, Melanie R. DeCorby, Heather J. Adam, Andrew Walkty, Daryl J. Hoban and George G. 2011. Zhanel Antimicrobial Resistance in Urinary Tract Pathogens in Canada from 2007 to 2009: CANWARD Surveillance Study, Antimicrob. Agents Chemother. 55(7): 3169-3175.

Kneebone, G.M. 1965. A clinical appraisalm 
of nalidixic acid in urinary tract infections in childhood. Med. $J$. Austaralia, 2: 947-49.

Legakis, N.J., Sakellar, P.R. \& Papavassiliou, J. 1979. In vitro sensitivity of Proteus organisms to gentamicin and sisomicin Chemotherapy, 25: 96-105.

Lode, $\mathrm{H}$. Studies on the in vitro effects of Cephalothin and Gentamicin, alone and in combination on Proteus mirabilis and enterococci. Infection, 3: 83-8.

Newman, R.L., Holt, R.J. \& Frankcombe, C.H. $1966 . \quad$ Nalidixic acid: microbiological and clinical studies on urinary infections in childhood. Arch. Dis. Childh., 41: 389-94.

Peterson, J., Kaul, S., Khashab, M., Fisher, A.C., Kahn, J.B. A double-blind, randomized comparison of levofloxacin $750 \mathrm{mg}$ once-daily for five days with ciprofloxacin $400 / 500 \mathrm{mg}$ twice-daily for 10 days for the treatment of complicated urinary tract infections and acute pyelonephritis. Urol., 71(1): 1722.

Population structure, virulence potential and antibiotic susceptibility of uropathogenic Escherichia coli from Northwest England, J. Antimicrob. Chemother., dkr451v1-dkr451.

Rossi, A., Galas, M., Tokumoto, M., Guelfand, L. \& Lopardo, H. 1990. In vitro activity of trorafloxacin of other quinolones and of related antimicrobials against clinical isolates. Groupo Colaborativo WHON-Argentina; 59(1): 8-16.

Shaikh, D., Ashfaq, S., Shaikh, K., Shaikh,
M., Naqvi, B.S., \& Majid, R. Studies on resistance / sensitivity pattern of bacteria related with urinary tract infections. Med. J. Islam. Acad. Sci. 15(4): 129-33.

Sharma, A. \& Grover, P.S. Application of whonet for the surveillance of antimicrobial resistance. Ind. J. Med. Microbiol., 22 (2): 115-118.

Sheina, E.P. \& Arutcheva, A.A. 1978. On susceptibility of Proteus clinical strains to antibiotics and their combination. Antibiotiki, 23: 424-28.

Shiba, T., Ohashi, N. \& Kamiya, K. Clinical use of Gentamicin in urinary tract infection due to Pseudomonas or Proteus. Acta Urology of Japan, 17: 601-4.

Stratford, B.C. Some observations on the use of ampicillin in urinary tract infection, Post-Graduated Med. J., 40: 68-74.

Tetsuro Muratani, Tetsuro Matsumoto Bacterial resistance to antimicrobials in urinary isolates, Int. J. Antimicrobial Agents, 24 (S1): 28-31. Proceedings of the 8th International Symposium on Clinical Evaluation of Drug Efficacy in Urinary Tract Infection.

Valdivieso, F., Trucco, O., Diaz, M.C. \& Ojeda. 1990. Antimicrobial resistance agents causing urinary tract infections in 11 Chilean hospital. Rev. Med. Chil., 127 (9): 1033-40.

Williams, G.J., Wei, L., Lee, A., Craig, J.C. 2006. Long-term antibiotics for preventing recurrent urinary tract infection in children. Cochrane Database Syst. Rev., 193: CD001534.

\section{How to cite this article:}

Firyal N. Aziz. 2016. Evaluation of Antibiotics Sensitivities against Some UTI Pathogens. Int.J.Curr.Microbiol.App.Sci. 5(11): 546-551. doi: http://dx.doi.org/10.20546/ijcmas.2016.511.065 